\title{
Short Communication: \\ Diversity and distribution of figs (Ficus spp.) across altitudes in Gunung Tilu, Kuningan, West Java, Indonesia
}

\author{
YAYAN HENDRAYANA ${ }^{1, \vartheta}$, PUDJI WIDODO ${ }^{2}$, CECEP KUSMANA ${ }^{3, \vee v}$, IMAM WIDHIONO ${ }^{2}$ \\ ${ }^{1}$ Faculty of Forestry, Universitas Kuningan. Jl. Tjut Nyak Dhien, Cijoho, Kuningan 45513, West Java, Indonesia. Tel.: +62-874824, Fax.: +62-232-873696, \\ "email: yayan.hendrayana@uniku.ac.id \\ ${ }^{2}$ Faculty of Biology, Universitas Jenderal Soedirman. Jl. Dr. Soeparno 63, Purwokerto, Banyumas 53122, Central Java, Indonesia \\ ${ }^{3}$ Department of Silviculture, Faculty of Forestry, Institut Pertanian Bogor. Jl. Raya Dramaga, IPB Dramaga Campus, Bogor 16680, West Java, Indonesia. \\ Tel.: +62-251-8626806, Fax.: +62-251-8626886, "`email: ck_mangrove@ gmail.com
}

Manuscript received: 1 February 2019. Revision accepted: 10 May 2019.

\begin{abstract}
Hendrayana Y, Widodo P, Kusmana C, Widhiono I. 2019. Short Communication: Diversity and distribution of figs (Ficus spp.) across altitudes in Gunung Tilu, Kuningan, West Java, Indonesia. Biodiversitas 20: 1568-1574. The genus of Ficus is significant component in tropical rainforest ecosystem, consisting of large number of species and spreading across altitudes. This research was aimed to examine the diversity and distribution of species belong to Ficus genus in Gunung Tilu, Kuningan District, West Java as a basis for building conservation strategies. There were 12 species of Ficus found from the altitudes of 600 to $1000 \mathrm{~m}$ asl. The highest number of species was found at the altitudes of $600-700 \mathrm{~m}$ above sea level with 10 species, while the lowest number of species were found at the altitudes above $1000 \mathrm{~m}$ asl with only two species. The highest individual density was found at an altitude of $600 \mathrm{~m}$ asl, while the lowest density was at the altitude of $1000 \mathrm{~m}$ asl. The distribution pattern of Ficus spreads throughout the region of Gunung Tilu, Kuningan.
\end{abstract}

Keywords: Distribution, diversity, Ficus spp., Gunung Tilu, lowland forests

\section{INTRODUCTION}

Figs, plant species from the genus of Ficus, is one of the major flora diversities in Southeast Asian tropical rainforests because of its ability to bear fruit throughout the year (Sreekar et al. 2010; Nason et al. 1998). This plant is wide-spread from tropical to subtropical zones of this region (Berg and Corner 2005). There are about 735 - 755 species from the genus of Ficus that have been identified by researchers (Berg and Corner 2005; van Noort and Rasplus 2004-2012). In Indonesia, the genus of Ficus can be found in large islands such as Sumatra 102 with species, Kalimantan with 106 species, Papua with 99 species, Sulawesi with 83 species, Java with 75 species, Maluku with 71 species and Nusa Tenggara with 36 species (Yusuf 2011). Figs can survive in various types of habitat ranging from rainforests, under canopies, and along rivers and cliffs (Burrows and Burrows 2003). In Malaysia region, they can be found in almost all types of terrestrial vegetation such as wet or dry land, rocky areas, primary and secondary forests, and in areas with altitude of less than $1,500 \mathrm{~m}$ asl (Berg and Corner 2005; Yusuf 2011). They have various forms of growth including hemiepiphytes (strangulation), large woody plants, climber, trees, and bushes (Pothasin et al. 2014).

Ficus are very important for pollinating and seed disperser animals (Mills et al. 1993), beetles (Harrison 2003) and fruit-eating birds (Lambert and Marshall 1991). They serve as source of food for mammals such as squirrels, civets (Lok et al. 2013), and primates (GautierHion 1980) including surili (Ruhiyat 1983), Javan langurs (Ihsanu et al. 2013), long-tailed monkeys (Chivers and Langer 1994), and Javan gibbons (Farida and Harun 2000). It can also function as tree for resting for fauna such as Tarsius sp. (Sinaga et al. 2012) and Macaca nigra (Lengkong 2011).

In addition to the benefits for animals, Ficus trees play important roles in ecological restoration, because the density and diversity of saplings of Ficus are two times higher than those from other genera, showing that it is more effective to use Ficus to restore degraded ecosystems compared to others. With regard to the composition of vegetation communities, the diversity index and dominance values of Ficus are also higher compared to others. These suggest that species from Ficus genus can support regeneration of plant communities in a landscape which does not only support the spread of fruiting plants, but can also develop new composition structures (Corbin and Holl 2012).

Gunung Tilu (Tilu Mountain) is one of lowland mountains located in the eastern part of Kuningan District. Until recently, information about the diversity of flora and fauna, especially Ficus spp., has not been deeply explored. Preliminary information gathered from community interviews revealed that these plants have no special importance. Nevertheless, understanding the diversity and distribution of species is important for environmental assessment of a landscape. It is generally known that trees 
with important values on the composition and structure of a vegetation community may have key functionalities of tropical forest ecosystems and can also serve as strong indicator of change in land cover. Based on these explanations, there is a need for research on the diversity, density and distribution of Ficus on the basis of spectrum of altitude for forest conservation in Gunung Tilu, Kuningan District and this is going to be the objective of this research. The results of this study can be used as reference to develop conservation strategies of Gunung Tilu forest area in Kuningan District.

\section{MATERIALS AND METHODS}

\section{Study area}

This research was carried out for three months in Gunung Tilu forest area in Kuningan District, which is located at $07^{\circ} 06^{\prime} 12,2^{\prime \prime}-07^{\circ} 07^{\prime} 48,1$ " North Latitude and $108^{\circ} 41^{\prime} 47,7^{\prime \prime}-108^{\circ} 41^{\prime} 39,0^{\prime \prime}$ East Longitude. The forest is categorized as lowland forest and a part of Bukit Pembarisan in the eastern part of Kuningan.
Administratively, Gunung Tilu is located in Jabranti Village, Karang Kancana Sub-district and Cimara Village, Cibingbin Sub-district, Kuningan District (Figure 1).

\section{Procedures}

Purposive sampling method was employed during data collection in the field (Notoadmodja 2010). Gunung Tilu forest area has an extent of 962 ha. Using Sampling Intensity (IS) of 1\%, resulting in sample plots of 9.62 ha which consists of 12 transects. Each transect was assigned to different altitude ranging from 500 to $1,000 \mathrm{~m}$ asl with each transect had a length of $100 \mathrm{~m}$ and a width of $20 \mathrm{~m}$. Variables observed included species richness and number of individuals, diameter (dbh), height of branch and total height for poles and trees. The distribution of Ficus was mapped by taking the coordinates of any point where they were found. Data were recorded simultaneously using Global Positioning System (GPS), field observation and vegetation analysis in order to analyze spatial distribution of the plants in Gunung Tilu, Kuningan District.

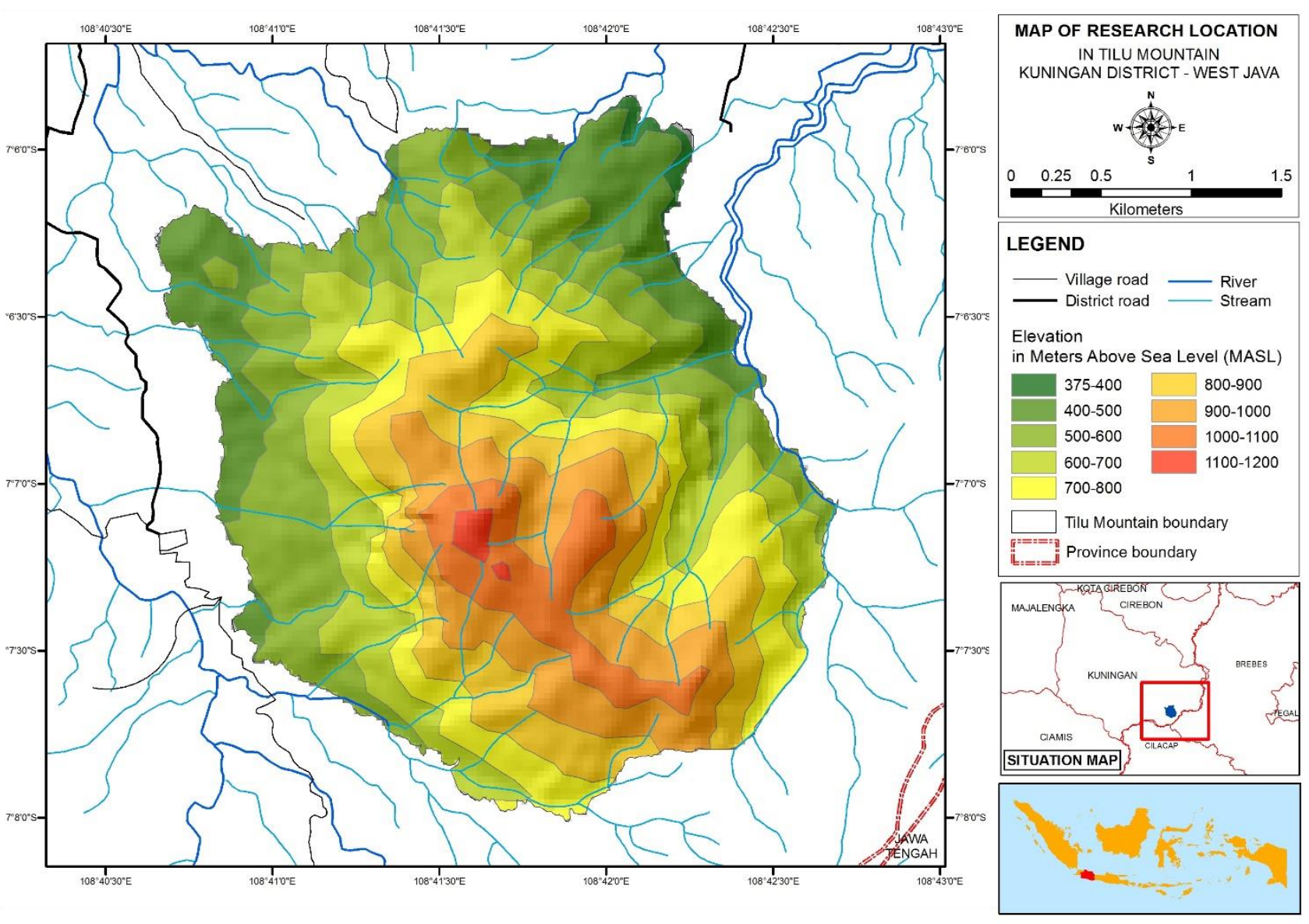

Figure 1. Location of Gunung Tilu, Kuningan District, West Java Province, Indonesia 
Table 1. The dominant species for each level of growth stage at various altitudes in Gunung Tilu, Kuningan District, West Java, Indonesia

\begin{tabular}{|c|c|c|c|c|c|c|c|c|}
\hline \multirow[b]{2}{*}{$\begin{array}{r}\text { Altitude } \\
\text { (m asl) }\end{array}$} & \multicolumn{8}{|c|}{ Dominant species } \\
\hline & Seedlings & $\begin{array}{l}\text { IVI } \\
(\%)\end{array}$ & Saplings & IVI (\%) & Poles & IVI (\%) & Trees & IVI $(\%)$ \\
\hline \multirow[t]{3}{*}{600} & Harpullia cupanioides & 12.01 & Harpullia cupanioides & 8.85 & Baccaurea javanica & 8.85 & Celtis tetrandra & 16.20 \\
\hline & Mitrephora obtusa & 10.08 & Mitrephora obtusa & 6.38 & Horsfieldia glabra & 6.38 & Bischofia javanica & 15.81 \\
\hline & Diospyros truncata & 8.98 & Mischocarpus fuscescens & 4.97 & Polyalthia lateriflora & 4.97 & Ficus sundaica & 15.24 \\
\hline \multirow[t]{3}{*}{700} & Cinnamoтит sintoc & 9.63 & Antidesma montanum & 9.63 & Diospyros truncata & 9.63 & Ficus sundaica & 19.10 \\
\hline & Tarenna polycarpa & 8.43 & Grewia laevigata & 8.43 & Polyalthia lateriflora & 8.43 & Sterculia campanulata & 17.34 \\
\hline & Aglaia odorata & 8.42 & Pterocymbium javanicum & 8.42 & Antidesma sp. & 8.42 & Neonauclea calycina & 14.62 \\
\hline \multirow[t]{3}{*}{800} & Polyalthia lateriflora & 6.77 & Harpullia cupanioides & 11.69 & Garcinia dioica & 15.49 & Celtis tetrandra & 22.85 \\
\hline & Antidesma sp. & 6.48 & Mallotus rufidulus & 10.22 & Mischocarpus fuscescens & 10.28 & Ficus drupacea & 13.78 \\
\hline & Mitrephora obtusa & 4.35 & Garcinia balica & 8.82 & Harpullia cupanioides & 7.42 & Ficus virens & 12.91 \\
\hline \multirow[t]{3}{*}{900} & Mallotus rufidulus & 17.31 & Harpullia cupanioides & 12.56 & Litsea glutinosa & 11.63 & Celtis tetrandra & 21.80 \\
\hline & Polyalthia subcordata & 16.98 & Baccaurea javanica & 11.79 & Harpullia cupanioides & 11.33 & Radermachera gigantea & 17.34 \\
\hline & Mischocarpus fuscescens & 15.41 & Sterculia oblongata & 11.15 & Sterculia oblongata & 8.21 & Neonauclea calycina & 15.46 \\
\hline \multirow[t]{3}{*}{1.000} & Bischofia javanica & 15.33 & Pittosporum ferrugineum & 4.93 & Pittosporum ferrugineum & 6.01 & Sterculia campanulata & 29.37 \\
\hline & Sterculia oblongata & 12.97 & Harpullia cupanioides & 4.93 & Dysoxylum parasiticum & 5.44 & Lithocarpus indutus & 23.30 \\
\hline & Lithocarpus indutus & 12.53 & Vitex quinata & 3.83 & Horsfieldia glabra & 4.12 & Bischofia javanica & 22.13 \\
\hline
\end{tabular}




\section{Data analysis}

Data analyzed included tree species density, species dominance, and species diversity. Tree species density was obtained by dividing total individuals of a species by total extent of sample plots. Important Value Index as presented by Kusmana (2017) was used to analyze species dominance while Shannon Index (Ludwig and Reynolds 1988) was used to measure species diversity. The greater is Shannon Index value $\left(\mathrm{H}^{\prime}\right)$, the higher is species diversity. The level of Shannon diversity index can be classified into three categories: $\mathrm{H}^{\prime}>3$ indicates high diversity; $1 \leq \mathrm{H}^{\prime} \leq 3$ indicates moderate diversity; and $\mathrm{H}^{\prime}<1$ indicates low diversity. The difference in tree density among altitudes was tested using SPSS 21. The statistical test used in this research is t-student.

The analysis of Ficus spp. distribution maps were conducted by obtaining and processing the Google Earth images through Arc Gis 10.2 computer software. Processing was carried out to get land cover maps, altitude maps, slope maps, and distance maps. Altitude and slope maps were produced by overlaying land cover maps with Landsat DEM image, while the distance map was obtained by applying spatial analysis tools using Euclidian distance.

\section{RESULTS AND DISCUSSION}

\section{Gunung Tilu vegetation}

Gunung Tilu area is classified as a lowland forest because of its vegetation species resemble this type of ecoregion with one of its peaks reaching an altitude of $1.200 \mathrm{~m}$ asl. From the observations of 48 sample plots, there were 145 species at tree stage, 159 species at pole stage, 140 species at sapling stage, and 141 species at seedling or ground cover stage. Plant species that dominates at tree level is kijungil (Celtis tetrandra) with Important Value Index (IVI) of 18,13\% while the lowest IVI was cauliflower (Xanthophyllum vitellinum) with IVI of $0,26 \%$. The relatively small of IVI value of $C$. tetrandra shows that tree vegetation in Gunung Tilu area tends to be heterogeneous.

The dominant species at the level of seedlings, saplings, poles, and trees at the altitude of $600 \mathrm{~m}$ asl were Harpullia cupanioides for seedlings and saplings, Baccaurea javanica for poles, and Celtis tetrandra for trees. At the altitude of $700 \mathrm{~m}$ asl, it was dominated by Cinnamomum sintoc for seedlings, Antidesma montanum for saplings, Diospyros truncata for poles, and Ficus sundaica for trees. Then, at an altitude of $800 \mathrm{~m}$ asl, it was dominated by Polyalthia lateriflora for seedlings, Harpullia cupanioides for saplings, Garcinia dioica for poles, and Celtis tetrandra for trees. Furthermore, at the altitude of $900 \mathrm{~m}$ asl, it was dominated by Mallotus rufidulus for seedlings, Harpullia cupanioides for saplings, Litsea glutinosa for poles, and Celtis tetrandra for trees. While, at the altitude of $1000 \mathrm{~m}$ asl, the dominating plants were Bischofia javanica (seedlings), Pittosporum ferrugineum (saplings and poles), and Sterculia campanulata (trees) (Table. 1).
In average, there was large number of species at each level of growth stage. Therefore, in general, the vegetation in Gunung Tilu can be classified as high diversity. Soerianegara and Indrawan (1988) emphasized that there is correlation between plants and habitat in terms of distribution of species, density, and dominance. A plant species is said to be dominant in a community if it is successful in utilizing most of the resources available for its growth compared to others.

\section{The diversity of Ficus spp.}

There were 12 species of Ficus spp. found in Gunung Tilu forest from the altitudes of 600 to $1.000 \mathrm{~m}$ asl. These included kiara beas (Ficus sundaica), kiara bunut (Ficus virens), kiara calodas (Ficus drupacea), karasak kara (Ficus kurzii), banyan tree (Ficus benjamina), kiara bonteng (Ficus globosa), kiara darangdang (Ficus sinuata), kondang (Ficus variegata), leles (Ficus glandulifera), kiara gembrong (Ficus copiosa), kiara karet (Ficus elastica) and hampelas (Ficus ampelas). At the altitude of $500 \mathrm{~m}$ asl, were found 6 species of Ficus. Then, at the altitude of 600 $\mathrm{m}$ asl, the majority of the area is directly adjacent to agricultural cultivation area and 10 species were found which is the highest number of species found among the observed altitudes. At the altitudes of 700 and $800 \mathrm{~m}$ asl, 8 species were found at each of these altitudes, while there were 5 species found at the altitude of $900 \mathrm{~m}$ asl. At the altitude above $1.000 \mathrm{~m}$ asl, only 2 species were found because of the closeness of this altitude to the peak of the mountain. Mulyasana (2008), said that the number of species generally decreases with increasing altitudes.

The total number of Ficus species found in this area is smaller than at Prof. Soemitro Djojohadikusumo conservation forest in PT. Tidar Kerinci Agung (TKA), Sumatera Barat with 20 species (Nur'aini et al. 2013), 27 species found at a lowland rainforest in Kalimantan (Harrison et al. 2003) and 32 species found at agricultural land in the Buganda region of Central Uganda (Ipulet 2008).

\section{Density of Ficus spp.}

There is great variation in the density of Ficus spp. based on altitude, from the lowest density of $0,42 \mathrm{ind} / \mathrm{ha}$ to the highest of $10 \mathrm{ind} / \mathrm{ha}$. At the altitude of $600 \mathrm{~m}$ asl, 10 species were found with the highest density including $F$. sundaica $(3,18 \mathrm{ind} / \mathrm{ha})$ while the lowest was $F$. calophylla, $F$. variegata, $F$. copiosa, and $F$. ampelas $(0,45 \mathrm{ind} / \mathrm{ha})$. At the altitude of $700 \mathrm{~m}$ asl, species with the highest density was $F$. sundaica $(3,33 \mathrm{ind} / \mathrm{ha})$ and while the lowest density were $F$. kurzii, $F$. variegata, and $F$. glandulifera with 0,42 ind/ha. At the altitude of $800 \mathrm{~m}$ asl, species with the highest density was $F$. calophylla (3,18 ind/ha) and the lowest density was $F$. globosa, $F$. sinuata, and $F$. Elastica $(0,45 \mathrm{ind} / \mathrm{ha})$. At the altitude of $900 \mathrm{~m}$ asl, $F$. virens was species with the highest density $(2,78 \mathrm{ind} / \mathrm{ha})$ while those of the lowest density were $F$. Kurzii, $F$. benjamina, and $F$. glandulifera $(0,56 \mathrm{ind} / \mathrm{ha})$. From these results, it could be seen that the density of Ficus spp. is decreasing along with increasing altitudes and this is in accordance with the results of research of Shanee and Peck (2008) in Northwest Equator. 


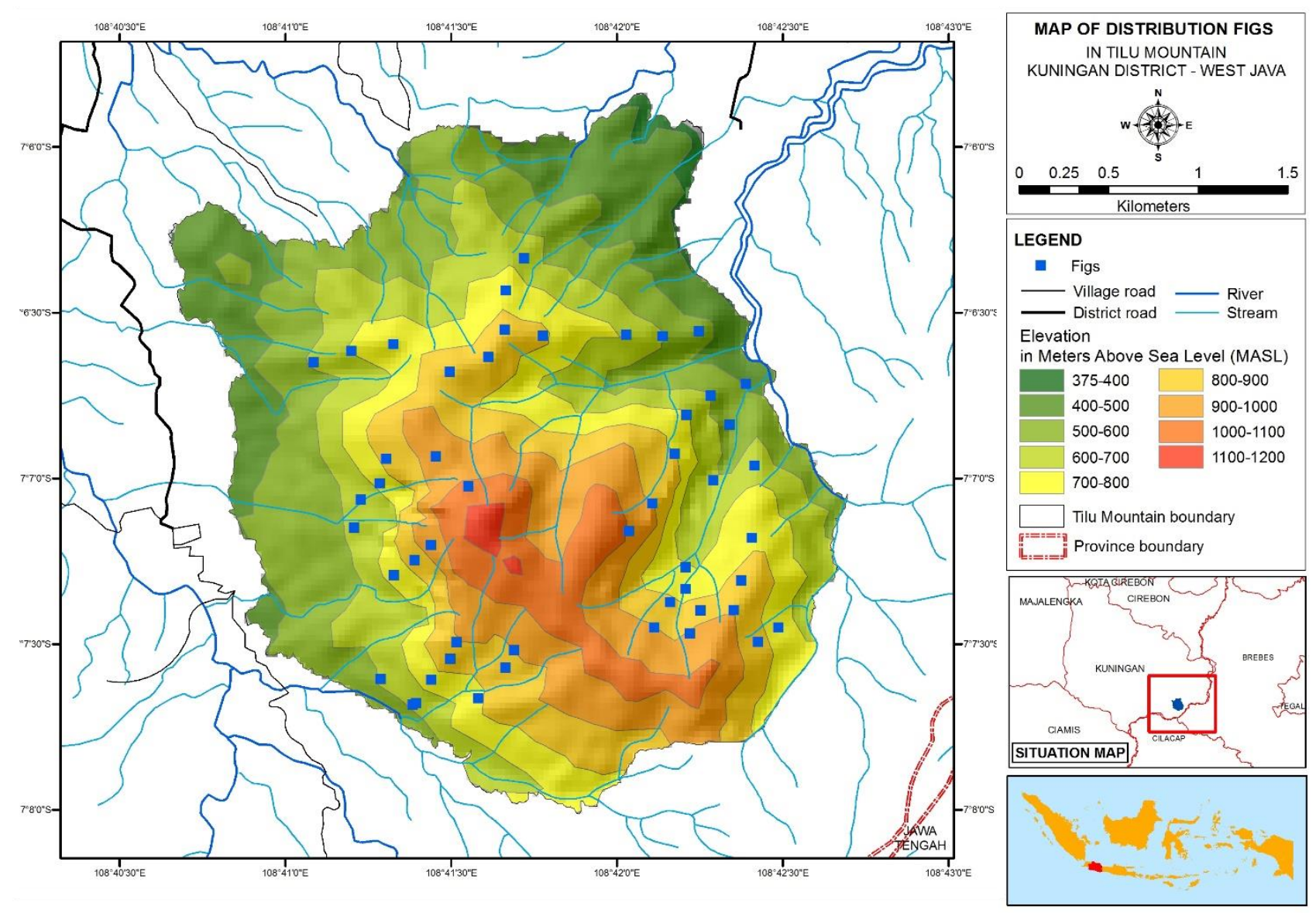

Figure 2. The distribution map of Ficus spp. in Gunung Tilu, Kuningan District, West Java, Indonesia

However, based on t-student tests carried out, the value of $\mathrm{F}=4,934$ and $\mathrm{P}=0,001$ were obtained which means that there are differences in the number of species at each altitude but there is no correlation between the number of species with altitude since the value of $\mathrm{R}=-0,196$ and $\mathrm{P}=$ 0,098 . From this analysis, it suggests that altitude does not affect the number of species of Ficus in Gunung Tilu, Kuningan District. Furthermore, density difference test resulted in the value of $\lambda 2=27,782 \mathrm{P}=0,000 \mathrm{~d} f=5$ which means that there is significant difference in individual density at each altitude but there is no correlation between density and altitude as the result of the $\mathrm{R}=-0,221$ with $\mathrm{P}=$ 0,062 . As such, it can be concluded that altitude does not affect the density of Ficus in Gunung Tilu, Kuningan District. In addition, based on the results, the presence of this plant could be found starting from an altitude of 500 to $1.000 \mathrm{~m}$ asl. However, not all species were found at every altitude, except $F$. sundaica. These results show that $F$. sundaica can life at altitude of $500 \mathrm{~m}$ asl until $900 \mathrm{~m}$ asl in Gunung Tilu.

\section{Distribution of Ficus spp.}

The distribution of Ficus spp. in Gunung Tilu area was started to be found at the altitude of $500 \mathrm{~m}$ asl until $1000 \mathrm{~m}$ asl with the highest distribution was observed at the altitude of $600 \mathrm{~m}$ asl. This finding is in line with Yusuf (2011) which states that Ficus species in the tropics are mostly found in lowlands and lower mountain forests with altitude of $<1500 \mathrm{~m}$ asl while there is few number of species are found in mountainous areas with altitudes of 1500-2500. Furthermore, Harrison (2005) said that in lowland tropical rainforests, Ficus is one of the most important plant genera. Based on GIS analysis, distribution of Ficus spp. in this study can be seen in Figure 2.

Based on the results (Table 4), distribution pattern of Ficus spp. in Gunung Tilu is clustered. Most tropical rainforest plant species have clustered spatial distribution pattern (Condit et al. 2000). In general, this can be caused by complex relationships of a number of factors, such as seed dispersal patterns (Bell 2000), competition for pollinators (Svenning 1999; Armbruster 1995), influence of population density (Webb and Peart 2000), the effects of disturbances (Molino and Sabatier 2001), as well as topographic variation and groundwater availability (Svenning 2001). Dolezal and Srutek (2002) revealed that distribution of a plant species is indirectly affected by interaction between the plant with temperature, air humidity, and other topographic conditions such as altitude and soil depth. Parikesit (1994) reported that in certain environmental conditions, each plant species spreads with different levels of adaptation and this determines the presence and absence of a particular plant species in an environment. 
Table 3. Species of Ficus in Gunung Tilu, Kuningan District, West Java, Indonesia and its density based on altitude

\begin{tabular}{lcccccc}
\hline \multicolumn{1}{c}{ Species } & \multicolumn{5}{c}{ Altitude } \\
\cline { 2 - 7 } & $\mathbf{5 0 0}$ ind/ha & $\mathbf{6 0 0}$ ind/ha & $\mathbf{7 0 0}$ ind/ha & $\mathbf{8 0 0}$ ind/ha & $\mathbf{9 0 0}$ ind/ha & $\mathbf{1 . 0 0 0}$ ind/ha \\
\hline F. sundaica & 1.67 & 2.92 & 3.33 & 1.25 & 0.83 & 0 \\
F. virens & 0.42 & 1.67 & 0 & 2.50 & 2.08 & 0 \\
F. calophylla & 0 & 0.42 & 2.08 & 2.92 & 1.25 & 0 \\
F. kurzii & 0.83 & 0.83 & 0.42 & 1.25 & 0.42 & 0 \\
F. benjamina & 0 & 2.08 & 0.83 & 0 & 0.42 & 0.42 \\
F. globosa & 0 & 1.25 & 0.42 & 0.42 & 0 & 0.83 \\
F. sinuate & 0.42 & 0 & 1.25 & 0.42 & 0 & 0 \\
F. variegate & 0.42 & 0.42 & 0.42 & 0.83 & 0 & 0 \\
F. glandulifera & 0 & 0.83 & 0.42 & 0 & 0 & 0 \\
F. copiosa & 0.83 & 0.42 & 0 & 0 & 0 & 0 \\
F. elastica & 0 & 0 & 0 & 0.42 & 0 & 0 \\
F. ampelas & 0 & 0.42 & 0 & 10.00 & 5.42 & 1.25 \\
& 4.58 & 11.25 & 9.17 & & 0 \\
\hline
\end{tabular}

Table 2. Diversity Index of Ficus spp.

\begin{tabular}{ccc}
\hline Altitude (m asl) & Total of species & Diversity Index (H') \\
\hline 500 & 6 & 1,64 \\
600 & 10 & 2,06 \\
700 & 8 & 1,75 \\
800 & 8 & 1,83 \\
900 & 6 & 1,58 \\
1000 & 2 & 0,63 \\
\hline
\end{tabular}

Table 4. Distribution pattern of Ficus spp. in Gunung Tilu, Kuningan District, West Java, Indonesia

\begin{tabular}{lc}
\hline Species & Distribution pattern \\
\hline Ficus sundaic & Clustered \\
Ficus virens & Clustered \\
Ficus drupacea & Clustered \\
Ficus kurzii & Clustered \\
Ficus benjamina & Clustered \\
Ficus globosa & Clustered \\
Ficus sinuata & Clustered \\
Ficus variegata & Clustered \\
Ficus glandulifera & Clustered \\
Ficus copiosa & Clustered \\
Ficus elastica & Clustered \\
Ficus ampelas & Clustered \\
\hline
\end{tabular}

In conclusion, Ficus spp. were found in Gunung Tilu at the altitude of $500 \mathrm{~m}$ asl until $1000 \mathrm{~m}$ asl. There were 12 species of Ficus that found in research location. The highest of number of species and density was found at an altitude of $600 \mathrm{~m}$ asl. Based on the results, altitude does not affect the density of Ficus in Gunung Tilu, Kuningan District. Distribution pattern of Ficus spp. in Gunung Tilu is clustered.

\section{ACKNOWLEDGEMENTS}

Our appreciation goes to Ditjen Risbang of Ministry of Research, Technology and Higher Education, Republic of Indonesia for funding this research. We also appreciate Perum Perhutani Divre West Java and Banten Province, Indonesia for giving us access to research location. We also thank Abdul Hakim, Ahmad, Rohman and Romi for their assistance in collecting data for this research.

\section{REFERENCES}

Armbruster WS. 1995. The origins and detection of plant community structure: reproductive versus vegetative processes. Folia Geobot 30 (4): 483-497.

Bell G. 2000. The distribution of abundance in neutral communities. Am Naturalist 155 (5): 606-617.

Berg CC, Corner EJH. 2005. Ficus-Moraceae. Flora Malesiana, Series I, 17: $1-730$.

Burrows J, Burrows S. 2003. Figs of southern \& south-central Africa. Umdaus Press, Hatfield.

Chivers DJ, Langer P. 1994. The Digestive System in Mammals: Food, Form and Function. Cambridge Univ Press, Australia.

Condit R, Ashton PS, Baker P, Bunyavejchewin S, Gunatilleke S, Gunatilleke N, Hubbell SP, Foster RB, Itoh A, LaFrankie JV, Lee HS, Losos E, Manokaran N, Sukumar R, Yamakura T. 2000. Spatial patterns in the distribution of tropical trees. Science 288: 1414-1418.

Corbin JD, Holl KD. 2012. Applied nucleation as a forest restoration strategy. For Ecol Manag 265: 37-46. DOI: 10.1016/j.foreco.2011.10.013

Dolezal J, Srutek M. 2002. Altitudinal Changes in Composition and Structure of Mountain-Temperate Vegetation: A Case Study from Western Carpathians. J Plant Ecol 158 (16): 201-221.

Farida WR, Harun. 2000. The diversity of plants as food resources for the Javan gibbon (Hylobates moloch), grizzled langur (Presbytis comata) and silver langur (Trachypithecus auratus) in Gunung Halimun National Park. J Primatol 3 (2): 55-61.

Gautier-Hion A. 1980. Seasonal variations of diet related to species and sex in a community of Cercopithecus monkeys. J Anim Ecol 49: 237269.

Harrison RD, Hamid AA, Kenta T, Lafrankie J, Lee HC, Nagamasu H, Nakazhisuka T, Palmiotto P. 2003. The diversity of hemi-epiphytic figs (Ficus; Moraceae)in a Bornean lowland rain forest. Biol J Linn Soc 78: 439-455.

Harrison RD. 2003. Fig wasp dispersal and the stability of a keystone plant resource in Borneo. Proc Biol Sci 270: S76-S79. 
Harrison RD. 2005. Figs and the Diversity of Tropical Rainforest. BioScience 55 (12): 1053-1064.

Ihsanu IA, Setiawan A, Rustiati EL. 2013. Studi perilaku makan dan analisis vegetasi pakan Lutung Jawa (Trachypithecus Auratus) di Taman Nasional Gunung Ciremai. J Silva Lestari 1 (1): 17-22. [Indonesian]

Ipulet P. 2008. Diversity of Genus Ficus L. (Moraceae) in farmlands and pastoral areas in Uganda Region, Central Uganda. Afr J Ecol 46: 5258

Kusmana C. 2017. Metode Survey dan Interpretasi data Vegetasi. PT Penerbit IPB Press, Bogor. [Indonesia]

Lambert FR, Marshall AG. 1991. Keystone characteristics of birddispersed Ficus in a Malaysian lowland rain forest. J Ecol 79: 793809.

Lengkong HJ. 2011. Laju Degradasi Habitat Monyet Hitam Sulawesi (Macaca Nigra) di Cagar Alam Gunung Duasudara Sulawesi Utara. J Ilmiah Sains 11 (1): 31-35.

Lok, A.F., W.F. Ang, B.Y.Q. Ng, T.M. Leong, C.K. Yeo, and H.T.W Tan. 2013. Native fig species as a keystone resource for the Singapore urban environment. Raffles Museum of Biodiversity Research, National University of Singapore, Singapore.

Ludwig JA, Reynold JF. 1988. Statistical Ecology. A. Primer on Method on Competing: John Willey and Sons, New York.

Mills LS, Soule ME, Doak DF. 1993. The keystone species concept in ecology and conservation. BioScience 43: 219-287.

Molino JF, Sabatier D. 2001. Tree diversity in tropical rain forests: a validation of the intermediate disturbance hypothesis. Science 294 (5547): 1702-1704.

Mulyasana 2008. Kajian keanekaragaman jenis pohon pada berbagai ketinggian tempat di Taman Nasional Gunung Ciremai Propinsi Jawa Barat. [Hon. Thesis]. Institut Pertanian Bogor, Bogor. [Indonesian]

Nason JD, Herre EA, Hamrick JL. 1998. The breeding structure of a tropical keystone plant resource. Nature 391: 685-687.

Nur'aini, Syamsuardi, Arbain A. 2013. Tumbuhan Ficus L. (Moraceae) di hutan konservasi Prof. Soemitro Djojohadikusumo, PT. Tidar Kerinc
Agung (TKA), Sumatera Barat. J Biologi Universitas Andalas. 2 (4): 235-241. [Indonesian]

Parikesit P. 1994. Composition and Structure of Cliff-Edge Forest in Relation to Some Environmental Gradients and Human Trampling. [Thesis]. University of Guelph, Ontario.

Pothasin P, Compton SG, Wangpakapattanawong P. 2014. Riparian Ficus tree communities: The distribution and abundance of riparian fig trees in Northern Thailand. PLoS ONE 9 (10): e108945. DOI: 10.1371/journal.pone.0108945..

Ruhiyat Y. 1983. Socio-ecological study of Presbytis aygula in West Java. Primates 24: 344-359.

Shanee S, Peck MR. 2008. Elevational changes in a neotropical Fig (Ficus spp.) community in North Western Ecuador. iForest-Biogeosciences For 1 (2): 104.

Sinaga W, Wirdatei, Iskandar E, Pamungkas J. 2012. Pengamatan Habitat, Pakan dan Sarang Tarsius (Tarsius sp.) Wilayah Sebaran di Sulawesi Tengah dan Gorontalo. Institut Pertanian Bogor, Bogor. [Indonesia]

Soerianegara, Indrawan A. 1988. Ekologi Hutan Indonesia. Fakultas Kehutanan, IPB, Bogor. [Indonesia]

Sreekar R, Le NTP, Harrison RD. 2010. Vertebrate assemblage at a fruiting fig (Ficus caulocarpa) in Maliau basin, Malaysia. Trop Conserv Sci 3: 218-227.

Svenning JC. 1999. Microhabitat specialization in a species-rich palm community in Amazonian Ecuador. J Ecol 87 (1): 55-65.

Svenning JC. 2001. On the role of microenvironmental heterogeneity in the ecology and diversification of Neotropical rain forest palms (Arecaceae). Bot Rev 67: 1-53.

Van Noort S, Rasplus JY. 2005. Revision of the Papua New Guinean fig wasp genus Robertsia Bouček (Hymenoptera, Chalcidoidea, Pteromalidae, Sycoecinae). Zootaxa 929: 1-35.

Webb CO, Peart DR. 2000. Habitat associations of trees and seedlings in a Bornean rain forest. J Ecol 88 (3): 464-478.

Yusuf R. 2011. Sebaran Ekologi dan Keanekaragaman Ficus spp. di Indonesia. Berk Penel Hayati Edisi Khusus: 5A (83-91). [Indonesian] 